\title{
Enhanced oil recovery ability of branched preformed particle gel in heterogeneous reservoirs
}

\author{
Long Yu, Qian Sang, and Mingzhe Dong* \\ Department of Chemical and Petroleum Engineering, University of Calgary, Calgary, AB T2N 1N4, Canada
}

Received: 24 March 2018 / Accepted: 13 September 2018

\begin{abstract}
Reservoir heterogeneity is the main cause of high water production and low oil recovery in oilfields. Extreme heterogeneity results in a serious fingering phenomenon of the displacing fluid in high permeability channels. To enhance total oil recovery, the selective plugging of high permeability zones and the resulting improvement of sweep efficiency of the displacing fluids in low permeability areas are important. Recently, a Branched Preformed Particle Gel (B-PPG) was developed to improve reservoir heterogeneity and enhance oil recovery. In this work, conformance control performance and Enhanced Oil Recovery (EOR) ability of B-PPG in heterogeneous reservoirs were systematically investigated, using heterogeneous dual sandpack flooding experiments. The results show that B-PPG can effectively plug the high permeability sandpacks and cause displacing fluid to divert to the low permeability sandpacks. The water injection profile could be significantly improved by B-PPG treatment. B-PPG exhibits good performance in profile control when the high/low permeability ratio of the heterogeneous dual sandpacks is less than 7 and the injected B-PPG slug size is between 0.25 and 1.0 PV. The oil recovery increment enhanced by B-PPG after initial water flooding increases with the increase in temperature, sandpack heterogeneity and injected B-PPG slug size, and it decreases slightly with the increase of simulated formation brine salinity. Choosing an appropriate B-PPG concentration is important for B-PPG treatments in oilfield applications. B-PPG is an efficient flow diversion agent, it can significantly increase sweep efficiency of displacing fluid in low permeability areas, which is beneficial to enhanced oil recovery in heterogeneous reservoirs.
\end{abstract}

\section{Introduction}

With the growing demand for energy resources and the depletion of oil and gas, how to extend the productive life of oil and gas reservoirs has become a challenging task for oilfield operators. High water production is the main cause of reduction in oil production and results in abandonment of producing wells. The water cut can be as high as $98 \%$ of the oil-water mixture brought to the surface for some oil wells [1], making reservoir development economically inefficient. High water production can result in other problems, such as increasing cost for water/oil processing, corrosion, and so on. Extreme reservoir heterogeneity is the primary factor responsible for excessive water production and low oil recovery in oilfields [2]. Many reservoirs have geologic formation heterogeneity problems. For instance, most oilfields in China have been discovered to be continental sedimentary reservoirs and are characterized by their severe permeability differences inside the reservoir formations $[3,4]$. In addition, long term water flooding or chemical flooding during the oilfield exploitation process may

\footnotetext{
* Corresponding author: mingzhe.dong@ucalgary.ca
}

lead to marked lateral and vertical heterogeneities in mature reservoirs [5-7]. Such heterogeneity, either geologically formed or resulting from the long-term flooding process, can cause early breakthrough of displacing fluid from the high permeability zones or water channels, leaving most residual oil in the low permeability zones un-swept which finally results in a high water cut in production wells and low overall sweep efficiency in oil formations [8]. Therefore, how to improve reservoir heterogeneity by effectively blocking the high permeability areas is crucial to water control and oil recovery enhancement.

Many methods have been used for profile control treatments in China to plug high permeability channels in reservoirs in order to reduce water production and increase sweep efficiency in low permeability zones. These methods include polymer flooding [9-11], foam flooding [12, 13], and so on. Adding polymer into the displacing water can significantly increase fluid viscosity, so the injected water can have a more uniform displacing front in heterogeneous reservoirs resulting from the improved water/oil mobility ratio. The combination of polymer and surfactant usually leads to higher sweep efficiency and higher displacing efficiency of a displacing fluid [14]. Some researchers tried 
to improve the property of polymer, such as using $\mathrm{PH}$ sensitive polymer, to enhance the oil recovery. The polymer solution was injected into formations at a lower viscosity in a low $\mathrm{PH}$ environment first, when the $\mathrm{PH}$ value returns to about 6 , the polymer solution becomes rigid, possessing high plugging strength [15]. However, due to prominent permeability differences between layers, it is very difficult for conventional polymer treatments to obtain good conformance control performance, especially in mature oilfields in which high permeability water channels exist [16]. For example, in Shengli oilfield, it is estimated that only $5 \% \sim 10 \%$ of the remaining oil can be improved by polymer flooding, and more than $50 \%$ residual oil is left in reservoirs [17]. The foam system can exhibit high flow diversion ability in some studies, and has been used as blocking agents in high permeability layers in heterogeneous reservoirs $[12,18]$. However, the stability property of the foam limits its wide applications in oilfields, as the foam may break up when in contact with residual oil [19]. Frampton et al. [20] tested highly expandable particulate materials in conformance control treatment. Their results showed that the swelling particles provide high resistance to fluid flow in formations, and can increase the total sweep efficiency of waterflood.

Gel treatment seems to be a traditionally used and costeffective conformance control technology that can plug high permeability zones, fractures and channels. The application of gel treatments in oilfields has proved to effectively reduce water cut, improve oil production and therefore extend the lives of productive wells [21-26]. In situ gel treatment requires that the polymer and the cross-linker are mixed and injected together into the formations. The polymer and the gelant will react to form gels at the reservoir temperature and pressure. The formed gels possess a certain strength and can plug the high permeability channels in the target formation [27-29]. However, due to in situ gels being cross-linked in the formation, this method inevitably has its distinct shortcomings. These include uncertainties of contact of polymer and gelant to form a gel system, limited control of the gelation time, difficulties controlling the stability and strength of the formed gel, adsorption, dilution and degradation of polymer in reservoirs, potential damage to the low permeability layers, and so on [30-32]. Another gel application for conformance control is preformed gel treatment. In this method, bulk gel is synthesized in surface facilities and cut into small particles. Gel particles are then injected into target formations for profile control. Such surface-synthesized particle gel is called Preformed Particle Gel (PPG). Because the gel is formed at the surface, it avoids the inherent disadvantages of the in situ gelation system. Additionally, PPG has only one component, so the operation process and injection facilities are much simpler than with the in situ method, and the injected particles are less sensitive to reservoir temperatures and formation water salinities [31].

Former studies have shown that PPG exhibits well conformance control performance in reservoirs existing high permeability zones/channels, both in laboratory experiments and pilot tests [33-39]. Coste et al. [33] investigated flow mechanisms of pre-gelled particles by transparent glass micro-model experiments. He found that gel particles can pass through pore throats in three ways: deformation of particle, shrinking of particle and breaking of particle, and the three-transport mechanisms can occur simultaneously. The pilot tests in his study show that pre-gelled particles exhibit in-depth fluid diversion ability and can re-distribute injecting water between heterogeneous formations and increase sweeping of the low permeability layer. Bai and Zhang [34] discussed PPG transport in open fractures and its effect on the following water flow. They discovered that injected PPG formed a gel pack in the fracture, and the subsequent water penetrated the permeable gel pack and formed water flow paths. PPG can reduce water permeability in fractures to the same level for different fracture widths. Imqam et al. [36] extensively examined blocking efficiency of PPG through conduit systems, which is helpful in designing millimeter size PPG plugging treatments for large openings or fractures. Elsharafi and Bai [37] studied factors affecting the damage caused to unswept oil areas by weak PPG during conformance control treatments. They concluded that millimeter-sized PPG cannot propagate in formations with permeability less than $320 \mathrm{mD}$, and the damage caused by PPG on unswept oil zones can be reduced significantly by changing the gel particle size and the formation brine salinity.

The traditional PPG is millimeter-sized particles. In recent years, a smaller-sized PPG, called Branched Preformed Particle Gel (B-PPG), was developed by Shengli oilfield in China [40]. B-PPG has some branches in its molecular structure which make the B-PPG system more viscous than traditional PPG suspension [41, 42]. Gong et al. $[43,44]$ discussed the synergistic effect of B-PPG and polymer/surfactant on Enhanced Oil Recovery (EOR) performance. Sang et al. [41] investigated the B-PPG transport mechanisms, using a micro-model and the EOR ability through sandpack flow tests. However, to date, no research has been found that systematically studies the factors influencing EOR performance on B-PPG in heterogeneous reservoirs. In this work, conformance control performance and EOR ability of B-PPG in heterogeneous reservoirs at different temperatures, salinities, reservoir heterogeneities, slug sizes and B-PPG concentrations are studied, using parallel dual sandpacks.

\section{Experimental}

\subsection{Materials}

The oil used in the experiments is crude oil obtained from Tuo four block, Shengli oilfield. Oil viscosity was measured using a Brookfield viscometer (DV-II+, Brookfield, USA) and was $68.4 \mathrm{mPa} . \mathrm{s}$ at a reservoir temperature of $70^{\circ} \mathrm{C}$. The water used is simulated formation brine, prepared from $\mathrm{CaCl}_{2}, \mathrm{MgCl}_{2} \cdot 6 \mathrm{H} 2 \mathrm{O}, \mathrm{NaCl}$ (Sinopharm Chemical Reagent Co. Ltd, Shanghai, PR China) and distilled water, with a salinity of $20000 \mathrm{mg} / \mathrm{L}$. Brines with different salinities (10 $000 \mathrm{mg} / \mathrm{L}$ and $5000 \mathrm{mg} / \mathrm{L}$ ) can be achieved by dilution of the initial simulated formation brine. The B-PPG sample was provided by the Research Institute of Geological 


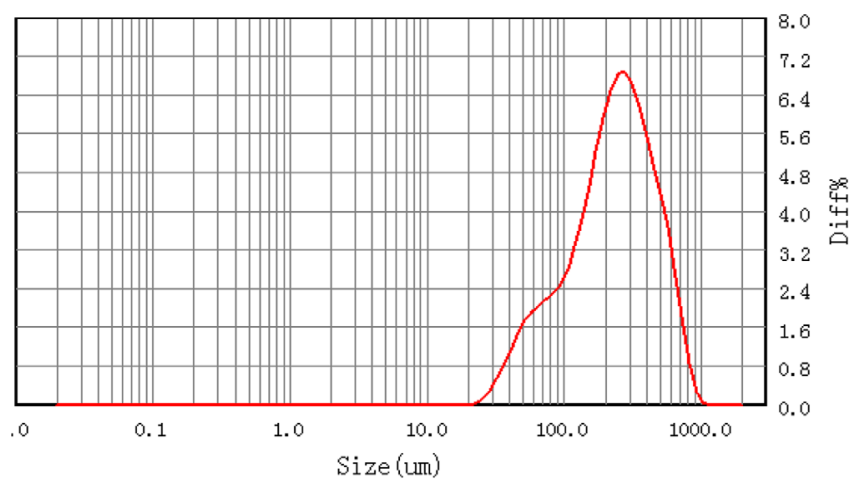

(a)

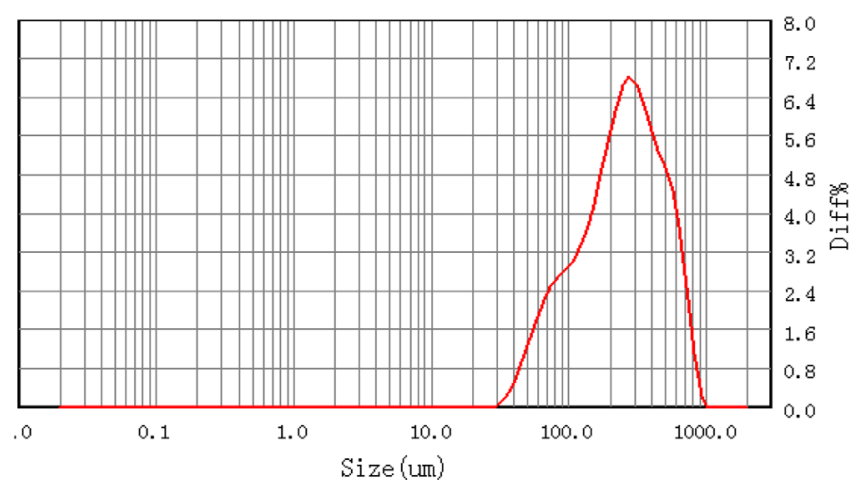

(b)

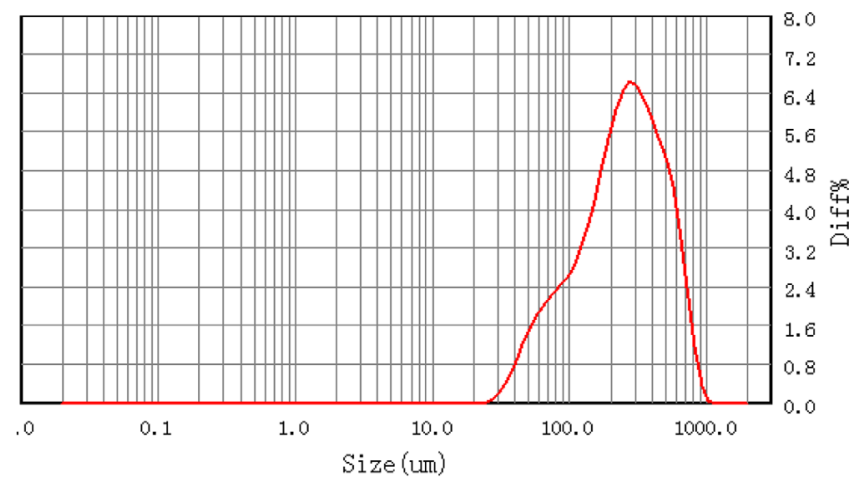

(c)

Fig. 1. Size distributions of swelled B-PPG in formation brines with different salinities: (a) $20000 \mathrm{mg} / \mathrm{L}$, (b) $10000 \mathrm{mg} / \mathrm{L}$, (c) $5000 \mathrm{mg} / \mathrm{L}$.

Science, Sinopec Shengli Oilfield Company. B-PPG particle possesses properties of both gel and water soluble polymer. In a water environment, the reticular molecule structure of B-PPG can adsorb water to form deformable soft cores. The branched chains of B-PPG are soluble in water, which can increase water viscosity. Therefore, the prepared B-PPG suspension was a visco elastic system. The dried $\mathrm{B}-\mathrm{PPG}$ particle used to prepare the B-PPG suspension is 140-160 mesh. When mixed with different salinity formation brines, particle size distributions of the swelled B-PPG were measured by a laser particle size distribution

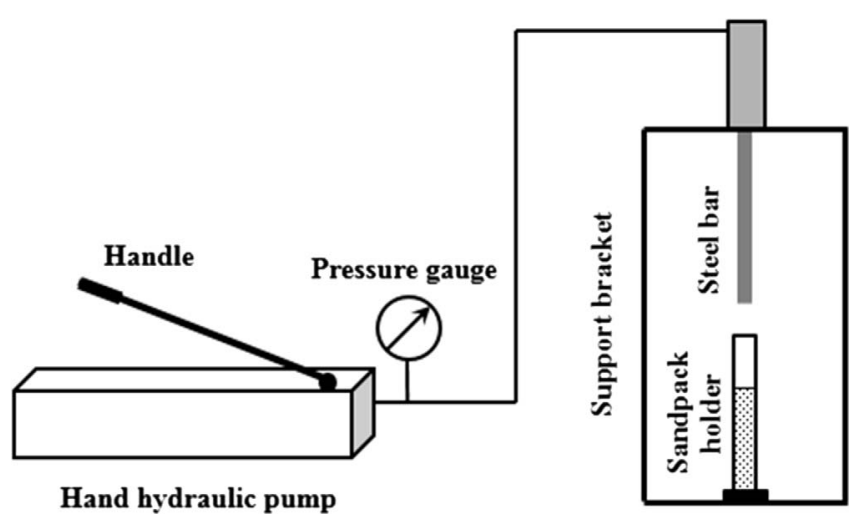

Fig. 2. Schematic diagram of the sand packer facility.

analyzer (Bettersize 2000, Dandong Better, PR China), as shown in Figure 1. The median diameters of the swelled B-PPG particles in formation brines with salinity of $20000 \mathrm{mg} / \mathrm{L}, 10000 \mathrm{mg} / \mathrm{L}$ and $5000 \mathrm{mg} / \mathrm{L}$ are $235.3 \mu \mathrm{m}$, $250.4 \mu \mathrm{m}$, and $251.0 \mu \mathrm{m}$, respectively, with size distribution ranges of $21.3 \mu \mathrm{m}-1028 \mu \mathrm{m}, \quad 21.3 \mu \mathrm{m}-1028 \mu \mathrm{m}$, and $27.1 \mu \mathrm{m}-1028 \mu \mathrm{m}$, respectively. B-PPG particles in the formation brines with different salinities have a similar particle size.

\subsection{Sandpack flood test}

The sandpack holders used in the flood tests were $30 \mathrm{~cm}$ in length and $2.5 \mathrm{~cm}$ in diameter. Quartz sands (Jiangsu Haian Petroleum Chemical Factory, PR China) with different meshes (40-60 mesh and 100-120 mesh) were used to prepare sandpacks with different permeabilities. The sandpacks were made at a sand-packer facility (Jiangsu Haian Petroleum Chemical Factory, PR China), which includes a hydraulic hand pump system, a support bracket, and a steel bar, as shown in Figure 2. The quartz sands were first washed carefully to remove impurities. The fresh sands, of specific amounts, were then added into the sandpack holder. The handle of the hydraulic hand pump was moved up and down to depress the steel bar into the sandpack holder. Once the bottom of the steel bar contacted the sands, the pressure shown in the pressure gauge increased. The movement of the pump handle was repeated until the pressure reached a specific value. The pressure was held for a specific time and the steel bar pressed the sands at this pressure. Pressure value and time were recorded and the pressure was then released. The process was repeated until the sandpack was fully prepared. The sandpack preparation had a high repeatability using this method. Changing the quartz sand mesh and amount, pressure and press time, sandpacks with different permeabilities could be prepared. Coarse sands (40-60 mesh) were used to prepare high permeability sandpacks, and fine sands (100-120 mesh) were used to prepare low permeability sandpacks. The newly packed sandpacks were vacuumed with a vacuum pump for $2 \mathrm{~h}$ and then saturated with the simulated formation brine. The Pore Volume (PV) and permeability, $k$, of the sandpacks were obtained by the mass balance method and Darcy's law measurements. 

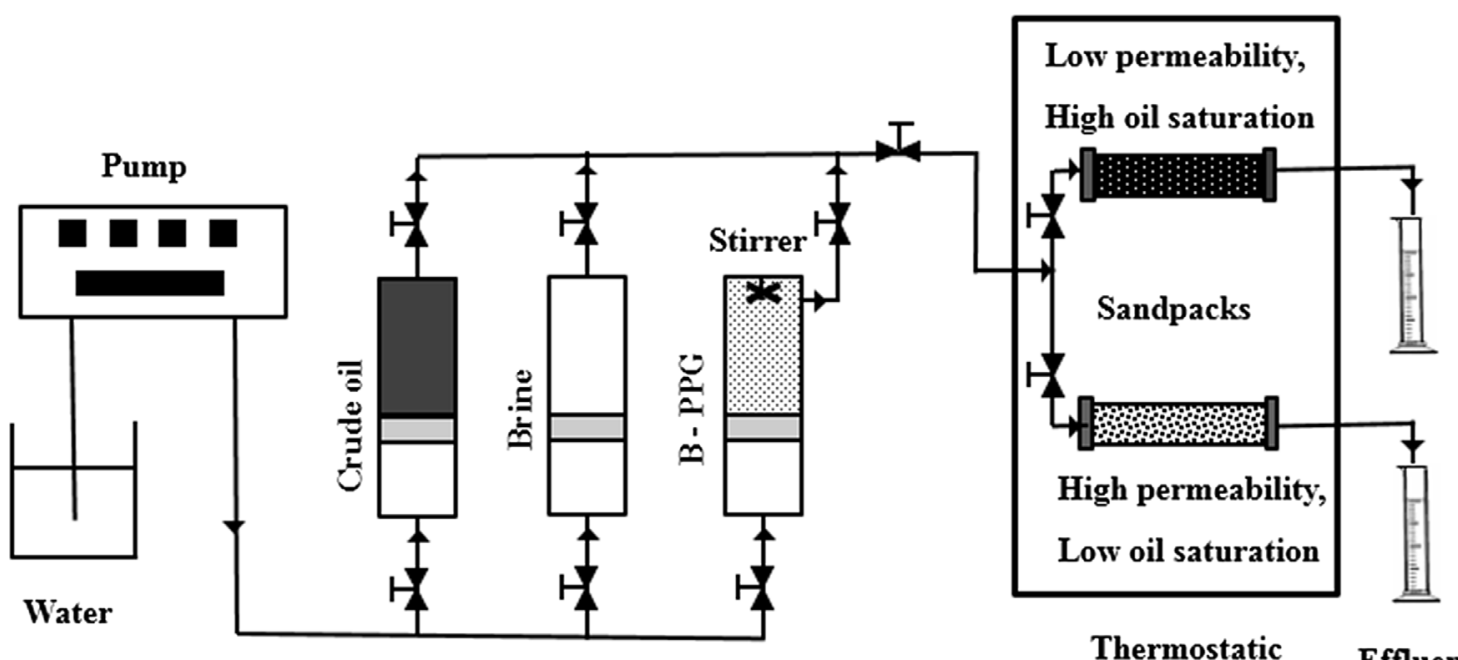

Thermostatic Effluents
water bath

Fig. 3. Schematic diagram of the parallel sandpack flooding setup.

The setup of the parallel dual sandpack flood tests is shown in Figure 3. It includes an injection pump (Teledyne $I S C O, U S A)$ to inject fluid at a specific flow rate, three cylinders to contain crude oil, formation brine and B-PPG, two parallel sandpacks with different permeabilities, a thermostatic water bath to maintain the required temperatures, and two graduated cylinders to collect the producing fluids for fractional flow and oil recovery analysis. An electric stirrer was placed inside the B-PPG cylinder. The B-PPG suspensions were stirred to prevent settlement of B-PPG particles during the injection process.

The procedure of the sandpack flood experiments is as follows: first, the vacuumed and saturated high permeability sandpack and low permeability sandpack were connected to the experimental setup, as in Figure 3. Second, sandpacks were placed into the constant temperature water bath at a required temperature for $30 \mathrm{~min}$ to ensure they were fully heated to the required temperature. Third, crude oil was injected into the high permeability sandpack and the low permeability sandpack separately at a flow rate of $0.1 \mathrm{~mL} / \mathrm{min}$ until the oil cut in the producing fluid was greater than $98 \%$. The volume of displaced water in the graduated cylinder was recorded, which was used to calculate initial oil saturation and irreducible water saturation of the sandpacks. Four, the sandpacks were kept in the water bath at the required temperature, aging for $72 \mathrm{~h}$ before being used for flood tests. Five, the simulated formation brine was injected into the heterogeneous dual sandpacks at a flow rate of $0.3 \mathrm{~mL} / \mathrm{min}$ until total water cut in the produced fluid was greater than $98 \%$. A specific slug size (PV) of the prepared B-PPG was then injected at the same flow rate. Subsequently, the formation brine continued to be injected until total water cut was up to $98 \%$ again. Fractional flows of total produced fluid, fractional flows of produced oil, and fractional flows of produced water in the high permeability sandpack and the low permeability sandpack were continuously recorded at the initial water flooding stage, B-PPG flooding stage and subsequent water flooding stage. Fractional flows were used to analyze profile control performance and EOR ability of the B-PPG. By changing the temperature, simulated formation brine salinity, sandpack permeability ratio, injected B-PPG slug size and B-PPG concentration, a series of sandpack flooding tests were conducted.

\section{Results and discussion}

\subsection{Profile control and oil recovery performance of B-PPG at different temperatures}

Figure 4 shows the fractional flows of the high permeability sandpacks and the low permeability sandpacks at different flooding stages and at different temperatures of $50{ }^{\circ} \mathrm{C}$, $70{ }^{\circ} \mathrm{C}$ and $90^{\circ} \mathrm{C}$, when injected by 0.5 PV slug size of B-PPG with concentration of $2000 \mathrm{mg} / \mathrm{L}$ at flow rate of $0.3 \mathrm{~mL} / \mathrm{min}$. The formation brine had a $20000 \mathrm{mg} / \mathrm{L}$ salinity in this set of tests.

Due to the heterogenity of the dual sandpacks, most of the injected water flows into the high permeability sandpack. Fractional flows of the high permeability sandpacks and the low permeability sandpacks show a significant difference. At the end of the water flooding process, the high-to-low fractional flow ratios are all above 90:10 for the three tests. After injection of B-PPG, fractional flows change rapidly. Fractional flow of the high permeability sandpack decreases and that of the low permeability sandpack increases significantly and then overtakes the fractional flow of the high permeability sandpack, showing immediate flow diversion. As the B-PPG injection continues, fractional flows of the high permeability sandpack and the low permeability sandpack exhibit fluctuation changes and become similar to each other. At the following water injection stage, fractional flows of the dual sandpacks still have fluctuating changes. This is because B-PPG has selective plugging ability when transported in porous 

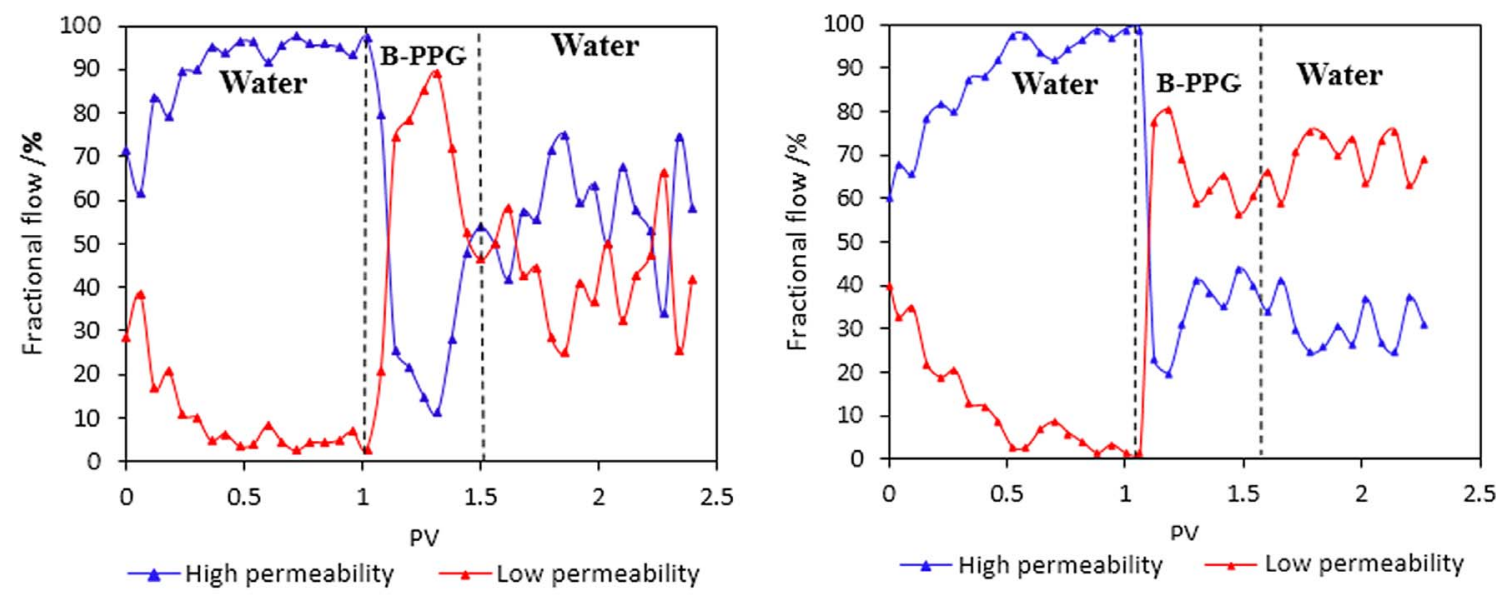

(a)

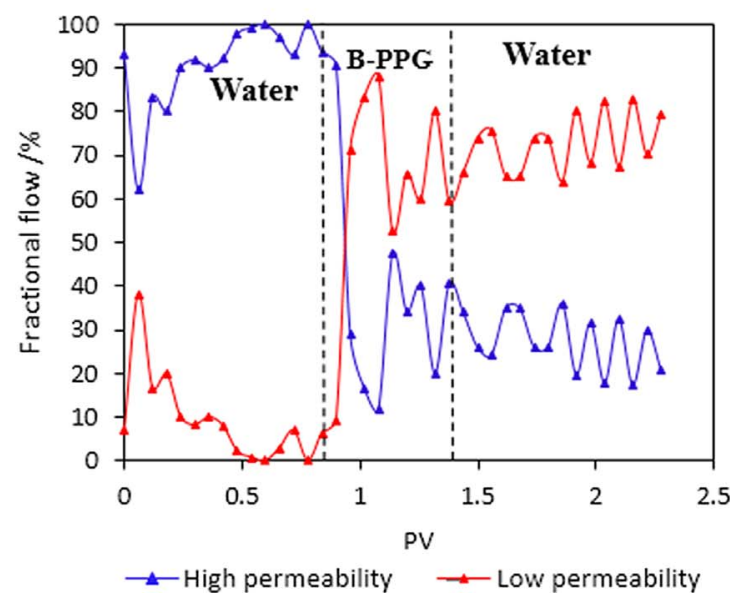

(b)

(c)

Fig. 4. Fractional flows of the heterogeneous sandpacks for B-PPG at different temperatures: (a) $50{ }^{\circ} \mathrm{C},(\mathrm{b}) 70{ }^{\circ} \mathrm{C},(\mathrm{c}) 90{ }^{\circ} \mathrm{C}$.

media. When B-PPG is injected after water flooding, due to the permeability difference, the visco elastic B-PPG particles are more likely to flow into and plug the high permeability sandpack, leading to greater flow resistance in the high permeability sandpack. Therefore, the following injected fluid would then flow into the low permeability sandpack, which causes an increase in fractional flow of the low permeability sandpack and a rapid flow diversion. As more and more B-PPG particles accumulate in the low permeability sandpack and plug the pores and throats flow resistance in the low permeability sandpack increases and fractional flow declines. Due to the visco elasticity of the B-PPG particle, it can deform itself to pass through the pore throats when transported in porous media under certain pressure gradients. In this way, B-PPG can alternatively and dynamically plug the high permeability sandpack and the low permeability sandpack, resulting in fluctuations in their fractional flows.

Figures $4 \mathrm{a}-4 \mathrm{c}$ demonstrate that after the B-PPG treatment, for a temperature of $50{ }^{\circ} \mathrm{C}$, fractional flows of the high permeability sandpack and the low permeability sandpack vary within the range of $30 \% \sim 70 \%$ in the subsequent water flooding process, and several flow diversions appear.
For temperatures of $70{ }^{\circ} \mathrm{C}$ and $90{ }^{\circ} \mathrm{C}$, fractional flows of the low permeability sandpacks are always greater than those of the high permeability sandpacks. High-to-low fractional flow ratios are around 30:70 at the subsequent water flooding stage. The results suggest that B-PPG can significantly improve the water injection profile for heterogeneous formations at different temperatures; temperature resistance properties and profile control ability are still effective after the flush of water. Compared to the sandpack flooding experiments, the flow of fluid in a matrix reservoir formation is a radial flow, not a linear flow as in sandpacks. The radial flow pattern could strongly affect the fluid flow distribution in the heterogeneous formations, resulting in a larger penetration degree of the conformance control fluid in low permeability area, which would lead to an increasing flow resistance in the low permeability formations and reduce the conformance control effect of gels [45]. However, the significant improvement of the fractional flow in heterogeneous sandpacks shown in Figure 4 still proves an effective conformance control ability by the B-PPG treatment. Moreover, in reservoirs with fractures, as the fluid flow in a fracture is linear (as in the sandpacks), B-PPG will be more easily applicable to the profile control. 
Table 1. Oil recovery of heterogeneous sandpacks at different temperatures.

\begin{tabular}{|c|c|c|c|c|c|c|c|c|c|}
\hline \multirow[b]{2}{*}{ Number } & \multirow[b]{2}{*}{ Sandpack } & \multirow[b]{2}{*}{ Porosity } & \multirow[b]{2}{*}{$\begin{array}{c}\text { Permeability } \\
\left(\mu \mathrm{m}^{2}\right)\end{array}$} & \multirow[b]{2}{*}{$\begin{array}{c}\text { Permeability } \\
\text { ratio }\end{array}$} & \multirow[b]{2}{*}{$\begin{array}{c}\text { Temperature } \\
\left({ }^{\circ} \mathrm{C}\right)\end{array}$} & \multirow[b]{2}{*}{$\begin{array}{l}\text { Oil viscosity } \\
\quad(\mathrm{mPa} s)\end{array}$} & \multicolumn{3}{|c|}{ Oil recovery (\%) } \\
\hline & & & & & & & $\begin{array}{l}\text { Water } \\
\text { flooding }\end{array}$ & $\begin{array}{c}\text { Subsequent } \\
\text { water flooding } \\
\text { after B-PPG } \\
\text { treatment }\end{array}$ & $\begin{array}{l}\text { Recovery } \\
\text { increment }\end{array}$ \\
\hline \multirow[t]{3}{*}{$\# 1$} & $k_{\text {high }}$ & 0.385 & 7.81 & 5.54 & 50 & 161.5 & 37.0 & 47.5 & 10.5 \\
\hline & $k_{\text {low }}$ & 0.370 & 1.41 & & & & 16.9 & 51.8 & 34.9 \\
\hline & Total & & & & & & 27.0 & 49.6 & 22.6 \\
\hline \multirow[t]{3}{*}{$\# 2$} & $k_{\text {high }}$ & 0.385 & 7.50 & 5.17 & 70 & 68.4 & 48.1 & 61.1 & 13.0 \\
\hline & $k_{\text {low }}$ & 0.369 & 1.45 & & & & 27.6 & 59.7 & 32.1 \\
\hline & Total & & & & & & 37.5 & 60.4 & 22.9 \\
\hline \multirow[t]{3}{*}{$\# 3$} & $k_{\text {high }}$ & 0.390 & 8.38 & 5.51 & 90 & 30.1 & 61.1 & 75.9 & 14.8 \\
\hline & $k_{\text {low }}$ & 0.372 & 1.52 & & & & 35.7 & 69.7 & 34.0 \\
\hline & Total & & & & & & 47.7 & 72.6 & 24.9 \\
\hline
\end{tabular}

Table 1 shows oil recovery results for the heterogeneous dual sandpacks at different temperatures. It can be seen that, due to the heterogeneity of the sandpacks, most recovered oil is displaced from the high permeability sandpacks when flooded by water. The low permeability sandpacks still have a high residual oil saturation after the water flooding process. The injection of B-PPG can effectively enhance oil recovery in the low permeability sandpacks by greatly improving sweep efficiency. The oil recovery factors for all the low permeability sandpacks at different temperatures have a more than 30\% increment after B-PPG treatment, compared to the water flooding process. The high permeability sandpacks also have a further over $10 \%$ oil recovery increase when flooded by B-PPG. Temperature has a significant effect on oil recovery. A lower temperature leads to smaller oil recovery. This is because oil viscosity increases greatly with a decrease of temperature, and a higher oil viscosity means a lower water-oil mobility ratio and lesser displacement efficiency. For different temperatures of $50{ }^{\circ} \mathrm{C}, 70{ }^{\circ} \mathrm{C}$ and $90{ }^{\circ} \mathrm{C}$, total oil recovery increments improved by B-PPG treatment were all above $20 \%$, indicating that B-PPG can significantly enhance oil recovery in heterogeneous reservoirs.

\subsection{Profile control and oil recovery performance of B-PPG with different salinities}

Figure 5 shows fractional flows of the high permeability sandpacks and the low permeability sandpacks in different flooding stages, with different formation water salinities of $5000 \mathrm{mg} / \mathrm{L}, 10000 \mathrm{mg} / \mathrm{L}$ and $20000 \mathrm{mg} / \mathrm{L}$ at $70{ }^{\circ} \mathrm{C}$ temperature when injected by $0.5 \mathrm{PV}$ slug size of B-PPG with concentration of $2000 \mathrm{mg} / \mathrm{L}$ at flow rate of $0.3 \mathrm{~mL} / \mathrm{min}$.

Figure 5 shows formation water salinities of $5000 \mathrm{mg} / \mathrm{L}$, $10000 \mathrm{mg} / \mathrm{L}$ and $20000 \mathrm{mg} / \mathrm{L}$, and flow diversion occuring after injection of B-PPG at the end of the water flooding process. For salinity of $5000 \mathrm{mg} / \mathrm{L}$, the "crossover" B-PPG slug size, where fractional flow of the low permeability sandpack overtakes that of the high permeability sandpack, is about $0.3 \mathrm{PV}$ (Fig. 5a). For salinity of $10000 \mathrm{mg} / \mathrm{L}$ and $20000 \mathrm{mg} / \mathrm{L}$, this "crossover" B-PPG slug size was about $0.1 \mathrm{PV}$ (Fig. 5b) and 0.05 PV (Fig. 5c). Higher formation water salinity results in a more rapid flow diversion in heterogeneous sandpacks. This is because the B-PPG particles in low salinity formation water are more flexible and deformable [34], so they have less plugging strength in the high permeability sandpacks than those particles prepared in high salinity water. At the subsequent water flooding stage, fractional flows of the high permeability sandpack and the low permeability sandpack for salinity of $5000 \mathrm{mg} / \mathrm{L}$ vary between $30 \%$ and $70 \%$, and for salinity of $10000 \mathrm{mg} / \mathrm{L}$ and $20000 \mathrm{mg} / \mathrm{L}$, fractional flow ratios of the high/low permeability sandpacks are around 30:70. This indicates that the B-PPG possesses a good salttolerant property and can still perform well with high formation water salinities.

Table 2 gives oil recovery results for the heterogeneous sandpacks with different formation water salinities. It can be seen that, after water flooding, oil recovery of the low permeability sandpacks can be greatly improved (more than $30 \%$ increment) by B-PPG injection. The final recovery factors of the low permeability sandpacks and the high permeability sandpacks are close to each other, indicating the heterogeneities of the dual sandpacks have been significantly improved through B-PPG treatment. All three pairs of heterogeneous sandpacks have a more than $20 \%$ total oil recovery increment after B-PPG flooding. Formation water salinity has some effect on oil recovery in heterogeneous reservoirs. The oil recovery factor slightly decreases as the formation water salinity increases. This is due to the fact that B-PPG particles in low salinity formation water possess a better deformability, so they can move into the depth of the sandpacks more easily than those with high salinity water, resulting in an in-depth profile control. 


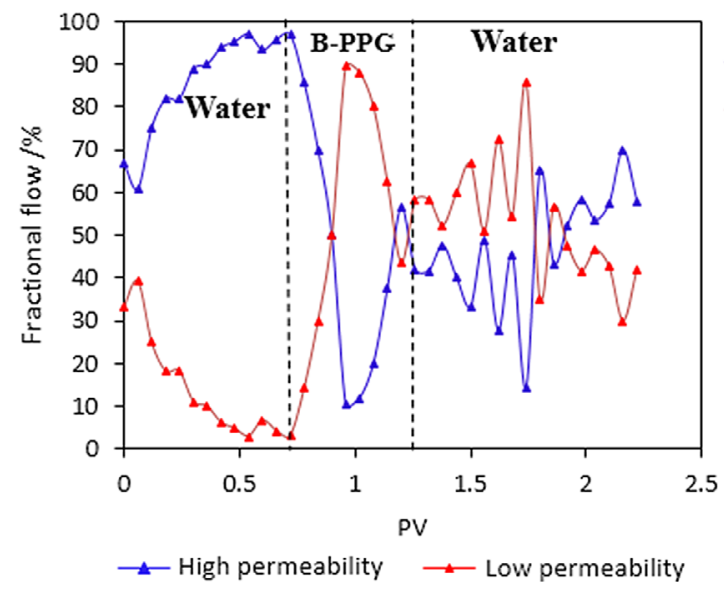

(a)

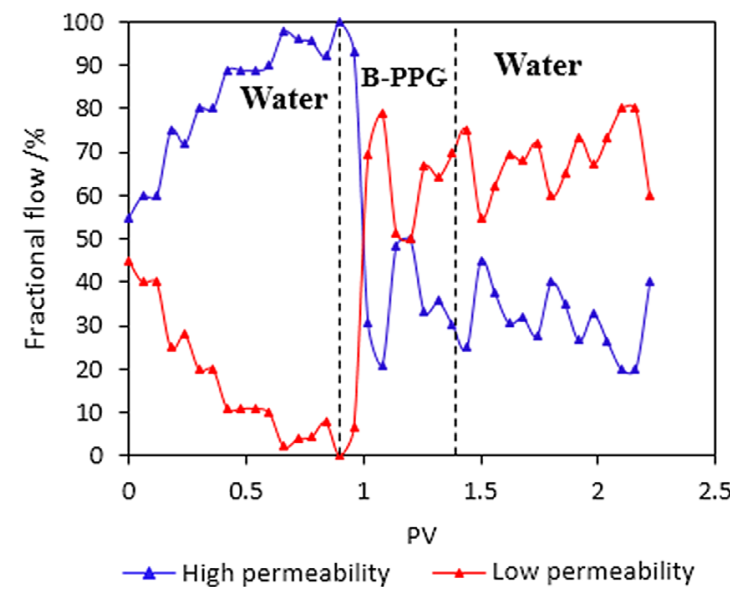

(b)

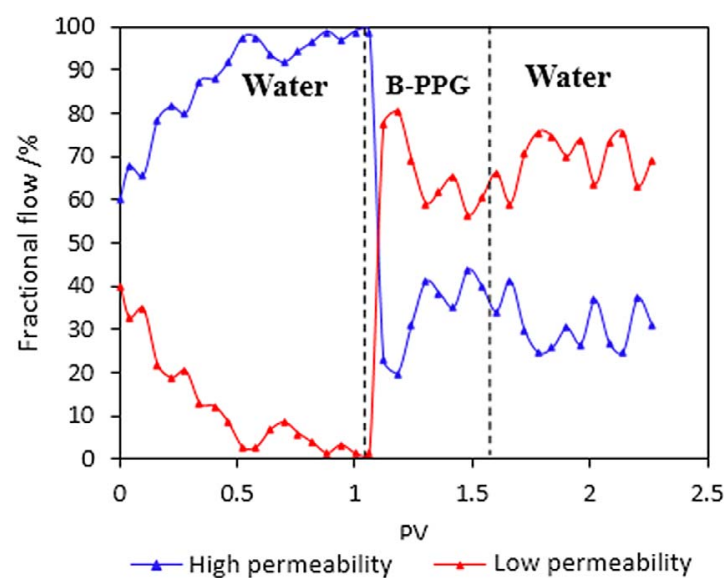

(c)

Fig. 5. Fractional flows of the heterogeneous sandpacks for B-PPG with different salinities: $5000 \mathrm{mg} / \mathrm{L}$, (b) $10000 \mathrm{mg} / \mathrm{L}$, (c) $20000 \mathrm{mg} / \mathrm{L}$.

Table 2. Oil recovery of heterogeneous sandpacks with different formation water salinities.

\begin{tabular}{|c|c|c|c|c|c|c|c|c|}
\hline Number & Sandpack & Porosity & $\begin{array}{l}\text { Permeability } \\
\qquad\left(\mu \mathrm{m}^{2}\right)\end{array}$ & $\begin{array}{c}\text { Permeability } \\
\text { ratio }\end{array}$ & $\begin{array}{l}\text { Salinity } \\
(\mathrm{mg} / \mathrm{L})\end{array}$ & \multicolumn{3}{|c|}{ Oil recovery (\%) } \\
\hline$\overline{\# 4}$ & $k_{\text {high }}$ & 0.388 & 7.96 & 5.31 & 5000 & 43.3 & 61.7 & 18.4 \\
\hline \multirow[t]{3}{*}{$\# 5$} & $k_{\text {high }}$ & 0.391 & 8.57 & 5.71 & 10000 & 45.2 & 61.8 & 16.6 \\
\hline & $k_{\text {low }}$ & 0.371 & 1.50 & & & 28.7 & 62.5 & 33.8 \\
\hline & Total & & & & & 37.0 & 62.1 & 25.1 \\
\hline \multirow[t]{2}{*}{$\# 2$} & $k_{\text {high }}$ & 0.385 & 7.50 & 5.17 & 20000 & 48.1 & 61.1 & 13.0 \\
\hline & $k_{\text {low }}$ & 0.369 & 1.45 & & & 27.6 & 59.7 & 32.1 \\
\hline
\end{tabular}




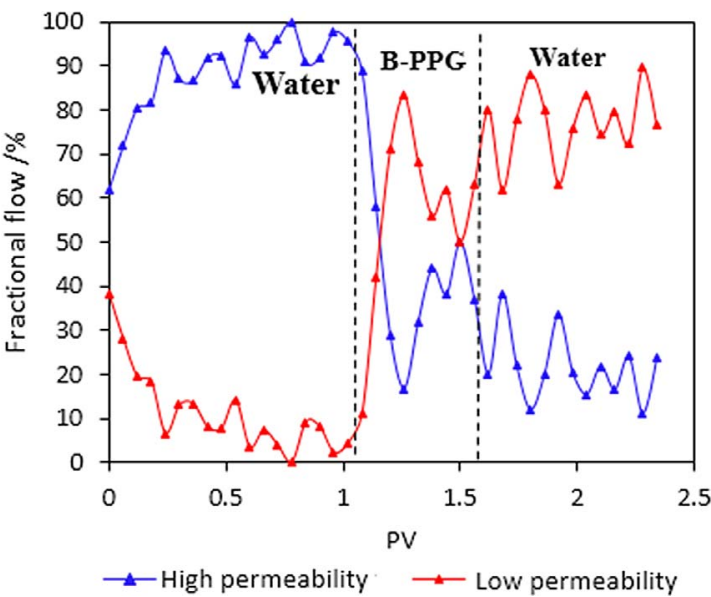

(a)

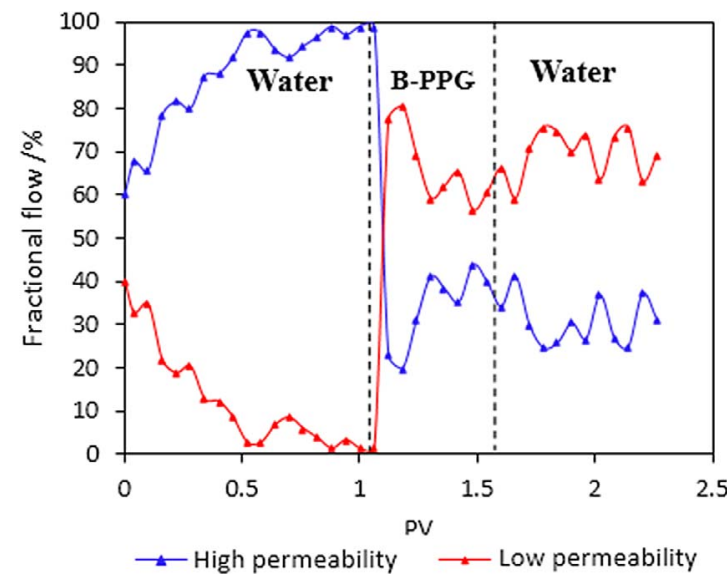

(b)

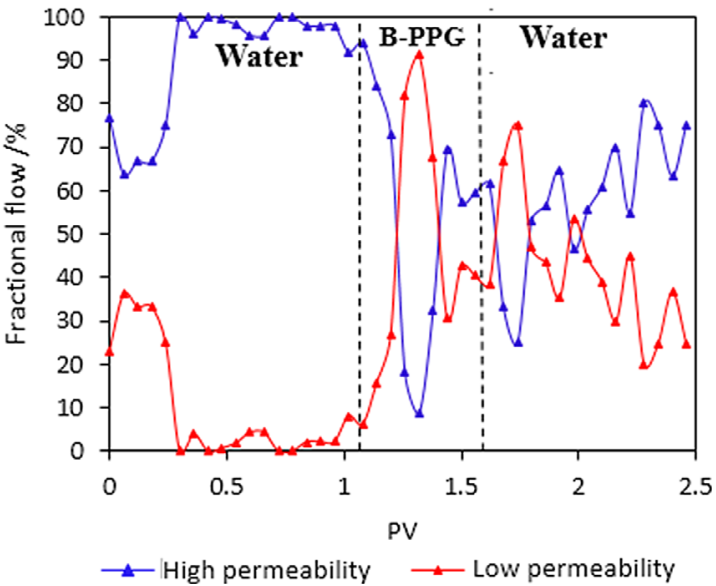

(c)

Fig. 6. Fractional flows of the heterogeneous sandpacks with different permeability ratios: (a) 2.88 , (b) 5.17 , (c) 7.50 .

\subsection{Profile control and oil recovery performance of B-PPG in sandpacks with different heterogeneities}

Figure 6 presents fractional flows of the heterogeneous dual sandpacks with different permeability ratios of $2.88,5.17$ and 7.50 when injected $2000 \mathrm{mg} / \mathrm{L}$ concentration of B-PPG with salinity of $20000 \mathrm{mg} / \mathrm{L}$ for $0.5 \mathrm{PV}$ slug size at flow rate of $0.3 \mathrm{~mL} / \mathrm{min}$ at $70^{\circ} \mathrm{C}$.

As we can see from Figure 6, B-PPG exhibits good selective plugging and flow diversion ability in dual sandpacks with different heterogeneities. For heterogeneous sandpacks with permeability ratio of 2.88 and 5.17, fractional flows of the low permeability sandpacks are always higher than those of the high permeability sandpacks. For heterogeneous sandpacks with the largest permeability ratio of 7.50, in the subsequent water flooding process, fractional flows occur several diversions, and the final high permeability/low permeability fractional flow ratio is around 60:40. We can also see from Figure 6 that the injected B-PPG slug size at which fractional flow of the low permeability sandpack overtakes fractional flow of the high permeability sandpack increases with an increase in sandpack heterogeneity. This is because as the permeability difference of the dual sandpacks increases, more B-PPG particles will be needed to move into the high permeability sandpacks to plug the flow paths before promoting flow diversion.

Table 3 gives oil recovery results for heterogeneous dual sandpacks with different permeability ratios. For a permeability ratio of 2.88 , oil recovery in the low permeability sandpack is improved by $22.7 \%$ after B-PPG treatment, compared to water flooding. For sandpacks with a permeability ratio of 5.17 , there is a $32.1 \%$ increment in oil recovery in the low permeability sandpack, and for a permeability ratio of 7.50 , the oil recovery increment is $39.8 \%$. The total oil recovery factors for the dual sandpacks with permeability of $2.88,5.17$ and 7.50 are $17.3 \%, 22.9 \%$ and $28.2 \%$, respectively. As we can see, the total oil recovery factor increases with an increase of sandpack heterogeneity, and most of the recovered oil is from the low permeability sandpacks. This is because in the sandpacks with extreme heterogeneity, the displacing water is more likely to break through from the high permeability sandpack in the water flooding process, leaving most of the residual oil in the low permeability sandpack unswept. This water channelling phenomenon results in lower total oil recovery and higher 
Table 3. Oil recovery of heterogeneous sandpacks with different permeability ratios.

\begin{tabular}{|c|c|c|c|c|c|c|c|}
\hline \multirow[b]{2}{*}{ Number } & \multirow[b]{2}{*}{ Sandpack } & \multirow[b]{2}{*}{ Porosity } & \multirow[b]{2}{*}{$\begin{array}{l}\text { Permeability } \\
\qquad\left(\mu \mathrm{m}^{2}\right)\end{array}$} & \multirow[b]{2}{*}{$\begin{array}{l}\text { Permeability } \\
\text { ratio }\end{array}$} & \multicolumn{3}{|c|}{ Oil recovery (\%) } \\
\hline & & & & & $\begin{array}{l}\text { Water } \\
\text { flooding }\end{array}$ & $\begin{array}{l}\text { Subsequent } \\
\text { water flooding } \\
\text { after B-PPG } \\
\text { treatment }\end{array}$ & $\begin{array}{l}\text { Recovery } \\
\text { increment }\end{array}$ \\
\hline \multirow[t]{3}{*}{$\# 6$} & $k_{\text {high }}$ & 0.387 & 7.7 & 2.88 & 43.8 & 55.9 & 12.1 \\
\hline & $k_{\text {low }}$ & 0.374 & 2.67 & & 35.2 & 57.9 & 22.7 \\
\hline & Total & & & & 39.8 & 57.1 & 17.3 \\
\hline \multirow[t]{3}{*}{$\# 2$} & $k_{\text {high }}$ & 0.385 & 7.5 & 5.17 & 48.1 & 61.1 & 13.0 \\
\hline & $k_{\text {low }}$ & 0.369 & 1.45 & & 27.6 & 59.7 & 32.1 \\
\hline & Total & & & & 37.5 & 60.4 & 22.9 \\
\hline \multirow[t]{3}{*}{$\# 7$} & $k_{\text {high }}$ & 0.396 & 12 & 7.50 & 45.3 & 61.5 & 16.2 \\
\hline & $k_{\text {low }}$ & 0.373 & 1.6 & & 23.0 & 62.8 & 39.8 \\
\hline & Total & & & & 34.1 & 62.3 & 28.2 \\
\hline
\end{tabular}

residual oil saturation in the low permeability sandpack. The fractional flow curves in Figure 6 show that B-PPG can effectively improve the water injection profiles in all of the tested dual sandpacks with different heterogeneities. Therefore, after B-PPG flooding, heterogeneous sandpacks with greater permeability difference would achieve a larger increment in sweep efficiency in the low permeability sandpack, and finally obtain a higher total residual oil recovery.

\subsection{Profile control and oil recovery performance of B-PPG with different injected slug sizes}

Figure 7 shows fractional flows of the high permeability sandpacks and low permeability sandpacks in different flooding stages when injected $2000 \mathrm{mg} / \mathrm{L}$ B-PPG with different slug sizes of $0.3 \mathrm{PV}, 0.5 \mathrm{PV}$ and $1.0 \mathrm{PV}$ at a flow rate of $0.3 \mathrm{~mL} / \mathrm{min}$ at $70{ }^{\circ} \mathrm{C}$. The formation water salinity is $20000 \mathrm{mg} / \mathrm{L}$.

After flooding by 1.0 PV slug size of B-PPG, fractional flows in the dual sandpacks show several flow diversions at the following flooding stages. When injected with B-PPG for a smaller slug size, such as $0.3 \mathrm{PV}$ (Fig. 7a) or $0.5 \mathrm{PV}$ (Fig. 7b), the fractional flows in the heterogeneous sandpacks also show a diversion. The producing fluid in the low permeability sandpack finally exceeds the producing fluid in the high permeability sandpack. It can also be seen from Figure 7 that the fractional flow difference between the high permeability sandpack and the low permeability sandpack increases as the injected B-PPG slug size decreases. When injecting $0.3 \mathrm{PV}$ of $\mathrm{B}-\mathrm{PPG}$, the fractional flow ratio of the high permeability sandpack and the low permeability sandpack is around 15:85. When the injected slug size increased to $0.5 \mathrm{PV}$, the fractional flow ratio fluctuates at around 30:70. This is due to the fact that when using $\mathrm{B}-\mathrm{PPG}$ for conformance control treatments in heterogeneous sandpacks, the visco elastic B-PPG particles would first selectively flow into the high permeability sandpack to increase the flow resistance to the fluid. If the injected B-PPG slug size is small, most of the injected B-PPG flowed into and plugged the high permeability sandpack, leading to resistance to fluid flow in the low permeability sandpack being smaller than that in the high permeability sandpack in the subsequent flooding stages. As the injected B-PPG slug size increases, after effectively blocking the high permeability sandpack, the following injected B-PPG will flow into the low permeability sandpack for plugging, resulting in increased flow resistance in the low permeability sandpack. Therefore, fractional flow in the low permeability sandpack declines and becomes closer to that of the plugged high permeability sandpack. As we can see, because of the alternative plug mechanism of B-PPG, a greater B-PPG slug size can make heterogeneous sandpacks more homogeneous.

Table 4 shows oil recovery results of heterogeneous sandpacks when treated by B-PPG flooding. The total oil recovery increment of the dual sandpacks increases with an increase of injected B-PPG slug size. After flooding by B-PPG with different slug sizes of $0.3 \mathrm{PV}, 0.5 \mathrm{PV}$ and 1.0 PV, the total oil recovery is improved by $20.1 \%, 22.9 \%$ and $24.2 \%$ at the end of the subsequent water flooding stage, compared to initial water flooding. As the injected B-PPG slug size increases, there will be more B-PPG particles flowing into the sandpacks. The visco elastic B-PPG particle not only possesses good conformance control performance, but also has oil displacement ability [46].

\subsection{Profile control and oil recovery performance of B-PPG with different concentrations}

Figure 8 shows the variations of fractional flows of the high permeability sandpacks and the low permeability sandpacks at different flooding stages when injected by $0.5 \mathrm{PV}$ of B-PPG with different concentrations of $1000 \mathrm{mg} / \mathrm{L}$, 


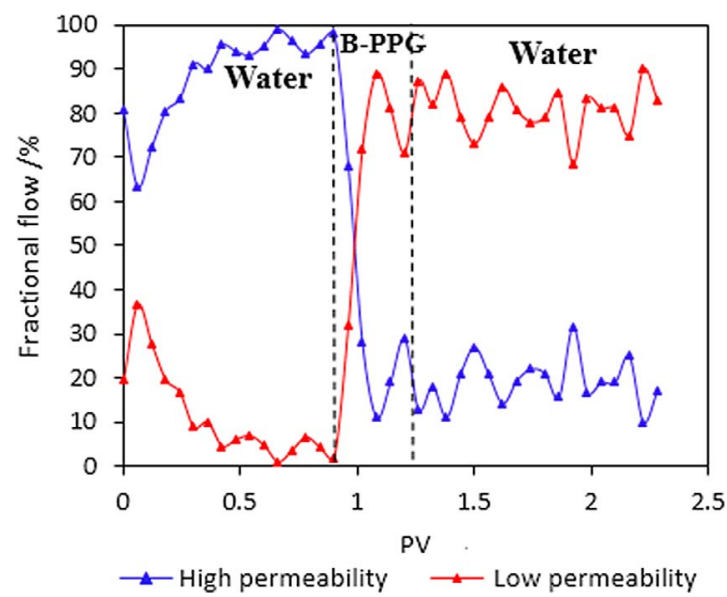

(a)

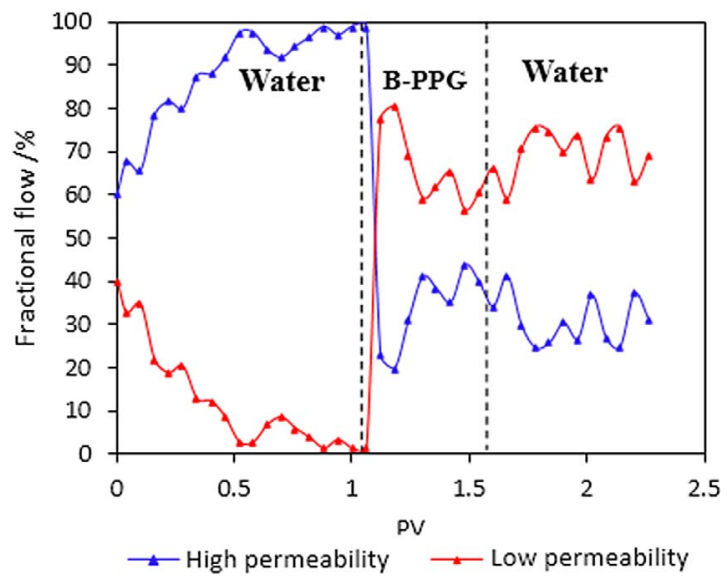

(b)

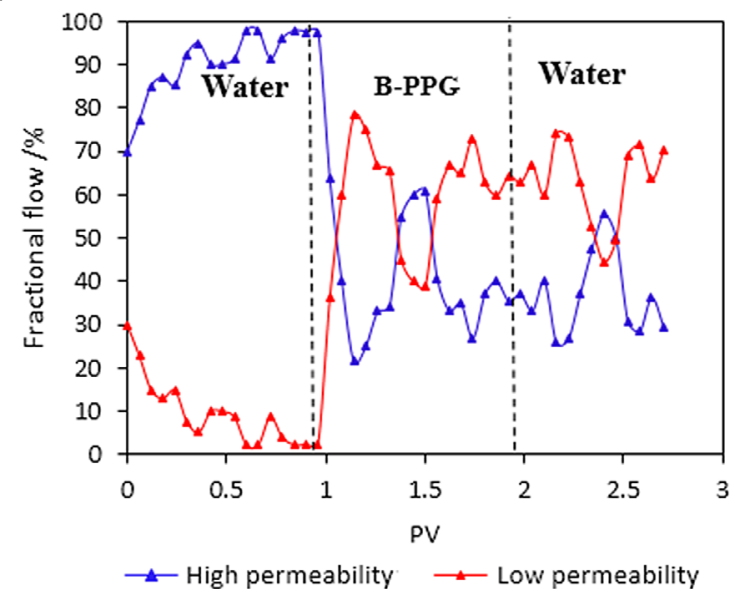

(c)

Fig. 7. Fractional flows of the heterogeneous sandpacks for B-PPG with different slug sizes: (a) 0.3 PV, (b) 0.5 PV, (c) 1.0 PV.

Table 4. Oil recovery of heterogeneous sandpacks with different injected B-PPG slug sizes.

\begin{tabular}{|c|c|c|c|c|c|c|c|c|}
\hline \multirow[b]{2}{*}{ Number } & \multirow[b]{2}{*}{ Sandpack } & \multirow[b]{2}{*}{ Porosity } & \multirow[b]{2}{*}{$\begin{array}{l}\text { Permeability } \\
\left(\mu \mathrm{m}^{2}\right)\end{array}$} & \multirow[b]{2}{*}{$\begin{array}{l}\text { Permeability } \\
\text { ratio }\end{array}$} & \multirow[b]{2}{*}{$\begin{array}{l}\text { B-PPG } \\
\text { slug } \\
\text { size/PV }\end{array}$} & \multicolumn{3}{|c|}{ Oil recovery $(\%)$} \\
\hline & & & & & & $\begin{array}{l}\text { Water } \\
\text { flooding }\end{array}$ & $\begin{array}{l}\text { Subsequent } \\
\text { water flooding } \\
\text { after B-PPG } \\
\text { treatment }\end{array}$ & $\begin{array}{l}\text { Recovery } \\
\text { increment }\end{array}$ \\
\hline \multirow[t]{3}{*}{$\# 8$} & $k_{\text {high }}$ & 0.389 & 8.2 & 5.39 & 0.3 & 41.0 & 53.6 & 12.6 \\
\hline & $k_{\text {low }}^{\circ}$ & 0.372 & 1.52 & & & 24.3 & 51.4 & 27.1 \\
\hline & Total & & & & & 32.4 & 52.5 & 20.1 \\
\hline \multirow[t]{3}{*}{$\# 2$} & $k_{\text {high }}$ & 0.385 & 7.5 & 5.17 & 0.5 & 48.1 & 61.1 & 13.0 \\
\hline & $k_{\text {low }}$ & 0.369 & 1.45 & & & 27.6 & 59.7 & 32.1 \\
\hline & Total & & & & & 37.5 & 60.4 & 22.9 \\
\hline \multirow[t]{3}{*}{$\# 9$} & $k_{\text {high }}$ & 0.382 & 6.9 & 5.75 & 1 & 42.1 & 54.5 & 12.4 \\
\hline & $k_{\text {low }}$ & 0.365 & 1.2 & & & 22.5 & 58.4 & 35.9 \\
\hline & Total & & & & & 32.4 & 56.6 & 24.2 \\
\hline
\end{tabular}




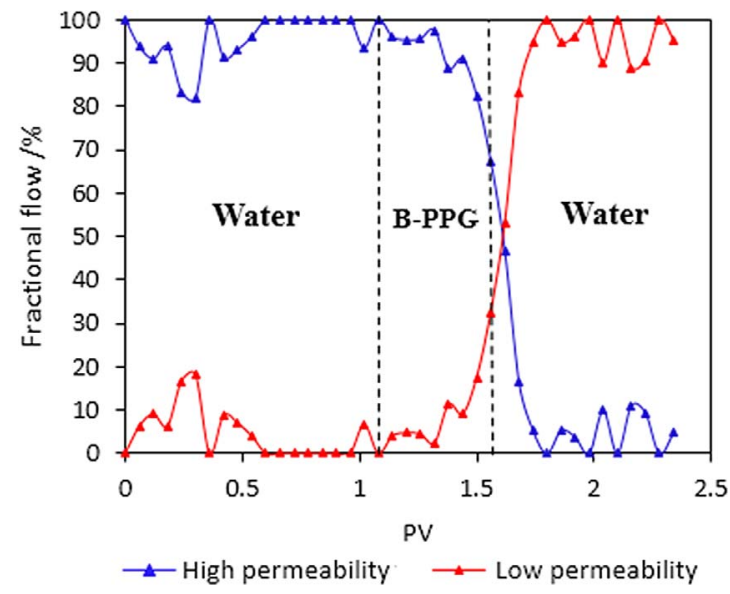

(a)

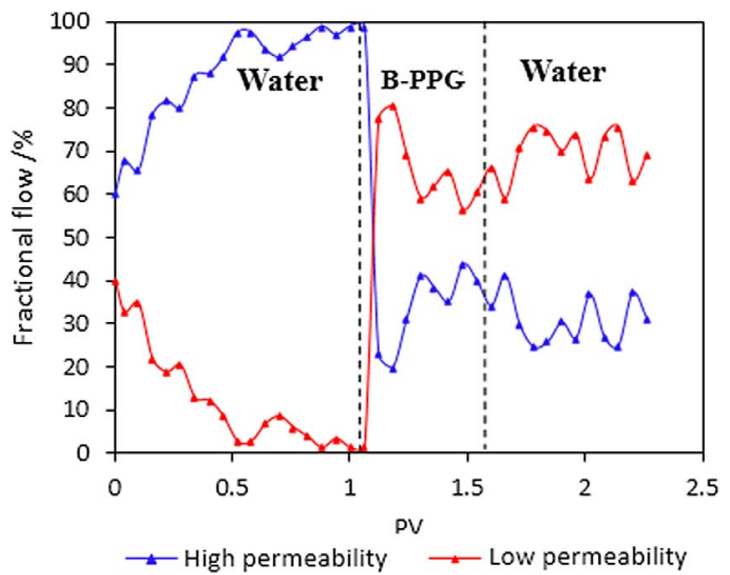

(b)

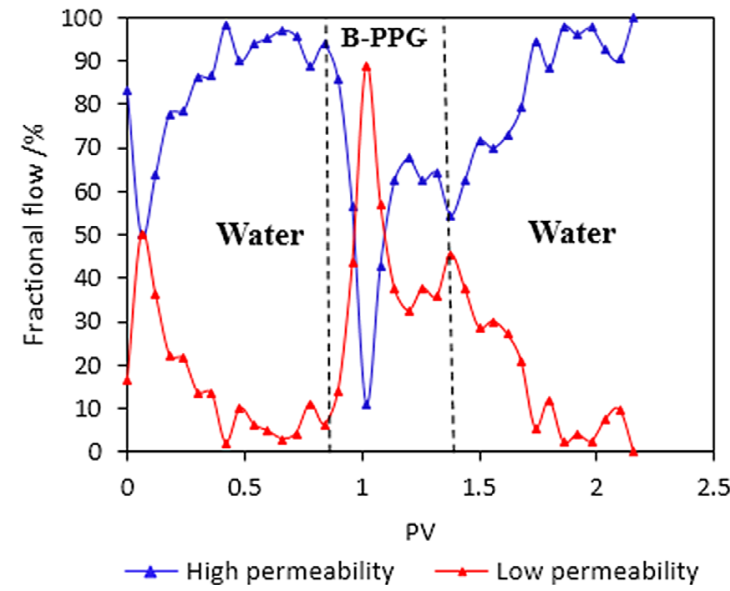

(c)

Fig. 8. Fractional flows of heterogeneous sandpacks for B-PPG with different concentrations: (a) $1000 \mathrm{mg} / \mathrm{L}$, (b) $2000 \mathrm{mg} / \mathrm{L}$, (c) $3000 \mathrm{mg} / \mathrm{L}$.

$2000 \mathrm{mg} / \mathrm{L}$ and $3000 \mathrm{~mL} / \mathrm{L}$ at a flow rate of $0.3 \mathrm{~mL} / \mathrm{min}$ at $70{ }^{\circ} \mathrm{C}$. The formation water concentration is $20000 \mathrm{mg} / \mathrm{L}$.

For injection of B-PPG with the lowest concentration of $1000 \mathrm{mg} / \mathrm{L}$, fractional flow of the high permeability sandpack decreases and that of the low permeability sandpack increases slowly. The intersection point where the fractional flow of low permeability overtakes the high permeability sandpack appears slowly (larger than 0.5 PV after B-PPG injection, Fig. 8a). For B-PPG with concentration of $2000 \mathrm{mg} / \mathrm{L}$, the flow diversion appears quickly and B-PPG shows good profile control performance, both in the B-PPG flooding process and the subsequent water flooding process (Fig. 8b). For B-PPG with the largest concentration of $3000 \mathrm{mg} / \mathrm{L}$, fractional flow of the low permeability sandpack first increases sharply and then declines again in the following flooding stages. B-PPG loses its profile control ability gradually at the subsequent water flooding stage, and the final fractional flow ratio of the high permeability sandpack and the low permeability sandpack reaches to above 90:10 (Fig. 8c). When injected B-PPG has a lower concentration, there will be fewer B-PPG particles flowing into sandpacks at a given injected slug size, causing a weaker plugging strength of the large pores and throats in sandpacks, and thus results in a slower flow diversion. Increasing the B-PPG concentration properly can help to improve blocking efficiency of B-PPG, but too high B-PPG concentration can lead to a too tight block of the sandpack, which is detrimental to the conformance control ability of B-PPG. Therefore, choosing B-PPG with appropriate concentrations is of great significance when using B-PPG for conformance control treatment in oilfields.

Table 5 gives oil recovery results for heterogeneous sandpacks at different flooding stages. The greatest overall oil recovery increment is $22.9 \%$ when flooded by $2000 \mathrm{mg} / \mathrm{L}$ B-PPG. For B-PPG with a concentration of $1000 \mathrm{mg} / \mathrm{L}$, the total oil recovery increment is $20.4 \%$, and for B-PPG with the greatest concentration of $3000 \mathrm{mg} / \mathrm{L}$, the total oil recovery has the least increment of $18.9 \%$. If B-PPG has a low concentration $(1000 \mathrm{mg} / \mathrm{L})$, a small number of B-PPG particles would be used for profile control and oil displacement in heterogeneous sandpacks. A higher concentration (2000 mg/L) provides a larger number of B-PPG particles which is sufficient for good oil recovery performance. However, B-PPG with too high concentration $(3000 \mathrm{mg} / \mathrm{L})$ 
Table 5. Oil recovery of heterogeneous sandpacks with different B-PPG concentrations.

\begin{tabular}{|c|c|c|c|c|c|c|c|c|}
\hline \multirow[b]{2}{*}{ Number } & \multirow[b]{2}{*}{ r Sandpack } & \multirow[b]{2}{*}{ Porosity } & \multirow[b]{2}{*}{$\begin{array}{l}\text { Permeability } \\
\qquad\left(\mu \mathrm{m}^{2}\right)\end{array}$} & \multirow[b]{2}{*}{$\begin{array}{l}\text { Permeability } \\
\text { ratio }\end{array}$} & \multirow[b]{2}{*}{$\begin{array}{l}\text { Concentration } \\
(\mathrm{mg} / \mathrm{L})\end{array}$} & \multicolumn{3}{|c|}{ Oil recovery (\%) } \\
\hline & & & & & & $\begin{array}{l}\text { Water } \\
\text { flooding }\end{array}$ & $\begin{array}{c}\text { Subsequent } \\
\text { water flooding } \\
\text { after B-PPG } \\
\text { treatment }\end{array}$ & $\begin{array}{l}\text { Recovery } \\
\text { increment }\end{array}$ \\
\hline \multirow[t]{3}{*}{$\# 10$} & $k_{\text {high }}$ & 0.385 & 7.43 & 4.82 & 1000 & 46.2 & 57.3 & 11.1 \\
\hline & $k_{\text {low }}$ & 0.373 & 1.54 & & & 21.9 & 51.6 & 29.7 \\
\hline & Total & & & & & 34.1 & 54.5 & 20.4 \\
\hline \multirow[t]{3}{*}{$\# 2$} & $k_{\text {high }}$ & 0.385 & 7.5 & 5.17 & 2000 & 48.1 & 61.1 & 13.0 \\
\hline & $k_{\text {low }}$ & 0.369 & 1.45 & & & 27.6 & 59.7 & 32.1 \\
\hline & Total & & & & & 37.5 & 60.4 & 22.9 \\
\hline \multirow[t]{3}{*}{$\# 11$} & $k_{\text {high }}$ & 0.390 & 8.5 & 4.94 & 3000 & 44.2 & 58.5 & 14.3 \\
\hline & $k_{\text {low }}$ & 0.374 & 1.72 & & & 29.6 & 53.4 & 23.8 \\
\hline & Total & & & & & 36.9 & 55.8 & 18.9 \\
\hline
\end{tabular}

can cause a tight block of the sandpack, leading to low sweep efficiency in the low permeability sandpack, and thus resulting in a low overall oil recovery factor.

The average pore size of the sandpacks with different permeabilities can be evaluated using equation (1) [47].

$$
r_{\mathrm{a}}=\sqrt{\frac{8 k}{\varphi}}
$$

where $r_{\mathrm{a}}$ is the average radius of porous media. The sandpacks used in the sandpack flow experiments have a permeability from $1.2 \mu \mathrm{m}^{2}$ to $12 \mu \mathrm{m}^{2}$, so the average radius of the sandpacks should be $5 \mu \mathrm{m}$ to $15 \mu \mathrm{m}$. Compared with the particle size of B-PPG, with diameters around $250 \mu \mathrm{m}$ and radius around $125 \mu \mathrm{m}$, the pore size is much smaller (about one tenth of the particle size), which also confirms that the prepared B-PPG particles possess a high deformability and flexibility.

\section{Conclusion}

Heterogeneous dual sandpack flooding tests were carried out in this study to systematically screen the parameters of temperature, formation brine salinity, reservoir heterogeneity, injected slug size and B-PPG concentration on the flow diversion efficiency of B-PPG in heterogeneous reservoirs with oil saturations. The major conclusions drawn from this study, based on the experimental results, are as follows:

1. The prepared B-PPG are viscoelastic particles. When transported in porous media, a B-PPG particle can deform itself to pass through the pore throats. The viscoelastic B-PPG particles can alternatively and dynamically plug the high permeability sandpack and the low permeability sandpack, and can significantly improve the water injection profile of heterogeneous sandpacks. B-PPG could still exhibit good conformance control performance after the flush of subsequent formation brine.

2. B-PPG has a high resistance to temperature and salinity. Total oil recovery could be improved by more than $20 \%$, and oil recovery of the low permeability sandpacks could be improved by more than $30 \%$, even at high temperatures (up to $90{ }^{\circ} \mathrm{C}$ ) and high salinity (up to $20000 \mathrm{mg} / \mathrm{L}$ ). B-PPG performs well in heterogeneous sandpacks with a high/low permeability ratio up to 7.5. The dual sandpacks with more extreme heterogeneity have a higher oil recovery increment after B-PPG flooding. This is because more oil was left in the low permeability sandpack when flooded by water in the more heterogeneous sandpacks, and B-PPG can effectively recover this remaining oil by diverting the displacing fluid to the un-swept area in the low permeability sandpack.

3. Overall oil recovery increases with an increase of injected B-PPG slug size; a larger slug size can make heterogeneous sandpacks more homogeneous. Properly increasing B-PPG concentrations can improve the oil recovery factor in heterogeneous reservoirs, but too high B-PPG concentrations can lead to a too tight block of the sandpack, causing damage to its conformance control and EOR ability. Therefore, choosing B-PPG with appropriate concentrations is significant for its applications in oilfields.

4. B-PPG flooding can greatly improve the permeability difference in heterogeneous reservoirs and substantially enhance oil recovery in low permeability layers. Increasing sweep efficiency to enhance oil recovery is the main mechanism of B-PPG flooding in heterogeneous reservoirs.

\section{References}

1 Veil J.A., Puder M.G., Elcock D., Elcock D., Redweik, Jr. R.J. (2004) A white paper describing produced water from 
production of crude oil, natural gas, and coal bed methane (No. $A N L / E A / R P$-112631), Argonne National Lab, IL, USA.

2 Elsharafi M.O., Bai B. (2012) Effect of weak preformed particle gel on unswept oil zones/areas during conformance control treatments, Ind. Eng. Chem. Res. 51, 35, 11547-11554.

3 Wang Y. (2007) Optimization of binary combination oil displacement system after polymer flooding in Shengli Oilfield, Petrol. Drill. Tech. 35, 5, 101-103.

4 Bai B., Li L., Liu Y., Liu H., Wang Z., You C. (2007) Preformed particle gel for conformance control: factors affecting its properties and applications, SPE Reserv. Evalu. Eng. 10, 04, 415-422.

5 Wang D. (2014) Some thoughts about potential of oil recovery efficiency and development model transition in Shengli district, Pet. Geol. Recovery Effic. 21, 4, 1-4.

6 Liu Z., Wang Q., Sun Y. (2014) Study and application of new technological limit for polymer flooding in field application, Petroleum Geology and Recovery Efficiency 21, 2, 22-24.

7 Liu Y., Bai B., Wang Y. (2010) Applied technologies and prospects of conformance control treatments in China, Oil Gas Sci. Technol. - Rev. IFP Energies nouvelles 65, 6, 859-878.

8 Liu X.E. (1995) Development and application of the water control and profile modification technology in China oil fields. SPE 2990\%, Paper Presented at International Meeting on Petroleum Engineering held in Beijing, China, 14-17 November.

9 Qin Y.F., Geng Z.Y., Bo J.Y., Ming Z.Z., Lei G.L., Fu J.Z. (2001) The practice and results of polymer flood programs at Shengli Oil Fields, Oilfield Chem. 18, 2, 148-151.

10 Zhang L. (2007) Technical and economic potential for polymer flooding in Shengli Oilfield, Petrol. Explor. Dev. 34, 1, 79-82.

11 Wang D., Zhao L., Cheng J., Wu J. (2003) Actual field data show that production costs of polymer flooding can be lower than water flooding. SPE International Improved Oil Recovery Conference in Asia Pacific, Society of Petroleum Engineers.

12 Zhang Y., Yue X., Yue X., Dong J., Yu L. (2000, January) New and effective foam flooding to recover oil in heterogeneous reservoir. SPE/DOE Improved Oil Recovery Symposium, Society of Petroleum Engineers.

13 Li Z., Zhou G., Zhou Z. (2006) The feasibility studies of polymer foam flooding in Gudao oilfield. SPE Asia Pacific Oil $\mathscr{G}$ Gas Conference and Exhibition, Society of Petroleum Engineers.

14 Yu L., Sun H.Q., Xiao J.H., Chen H., Song D.F., Zheng L.Q., Li G.Z. (2007) SDCM-1/HPAM surfactant/polymer combinational flooding fluid for further enhanced oil recovery after polymer flood finished, Oilfield Chem. 24, 4, 355-358.

15 Al-Anazi H.A., Sharma M.M. (2002, January) Use of a pH sensitive polymer for conformance control. International Symposium and Exhibition on Formation Damage Control, Society of Petroleum Engineers.

16 Zhao F.L., Wang Y.F., Dai C.L., Ren S., Jiao C. (2006) Techniques of enhanced oil recovery after polymer flooding, Journal of China University of Petroleum: Edition of Natural Science 30, 1, 86-89.

17 Zhang L., Cui X., Ren S. (2010) The study on enhanced oil recovery technology in reservoirs after polymer flooding, Chem. Eng. Oil Gas 39, 2, 144-147+88.

18 Farajzadeh R., Andrianov A., Zitha P.L. (2009) Investigation of immiscible and miscible foam for enhancing oil recovery, Ind. Eng. Chem. Res. 49, 4, 1910-1919.
19 Gong H., Zhang H., Xu L., Li K., Yu L., San Q., Li Y., Dong M. (2017) The synergistic effect of branched-preformed particle gel and hydrolyzed polyacrylamide on furtherenhanced oil recovery after polymer flooding, Energy Fuels 31, 8, 7904-7910.

20 Frampton H., Morgan J.C., Cheung S.K., Munson L., Chang K.T., Williams D. (2004, January) Development of a novel waterflood conformance control system. SPE/DOE Symposium on Improved Oil Recovery, Society of Petroleum Engineers.

21 Diaz D., Somaruga C., Norman C., Romero J.L. (2008, Jan) Colloidal dispersion gels improve oil recovery in a heterogeneous Argentina waterflood, SPE Symposium on Improved Oil Recovery, Society of Petroleum Engineers.

22 Kabir A.H. (2001) Chemical water and gas shutoff technology - an overview. SPE Asia Pacific Improved Oil Recovery Conference and SPE/DOE Symposium on Improved Oil Recovery, Society of Petroleum Engineers.

23 Der Sarkissian J., Prado M., Rauseo O., Rauseo O. (2005) Lessons learned from four selective water shutoff treatments in mature reservoirs in Maracaibo Lake. Offshore Europe, Society of Petroleum Engineers.

24 Zitha P.L., Darwish M.M. (1999) Effect of bridging adsorption on the placement of gels for water control. SPE Asia Pacific Improved Oil Recovery Conference, Society of Petroleum Engineers.

25 Wang Y., Bai B., Gao H., He L., Zhao F. (2008) Enhanced oil production through a combined application of gel treatment and surfactant huff'n'puff technology. SPE International Symposium and Exhibition on Formation Damage Control, Society of Petroleum Engineers.

26 Borling D.C. (1994, January) Injection conformance control case histories using gels at the Wertz Field $\mathrm{CO}_{2}$ tertiary flood in Wyoming. SPE/DOE Improved Oil Recovery Symposium, Society of Petroleum Engineers.

27 Sydansk R.D., Southwell G.P. (2000) More than 12 years of experience with a successful conformance-control polymer gel technology. SPE/AAPG Western Regional Meeting, Society of Petroleum Engineers.

28 Wouterlood C.J., Falcigno E.D., Gazzera C.E., Norman C.A. (2002) Conformance improvement with low concentration polymer gels in a heterogeneous, multilayer reservoir. SPE/DOE Improved Oil Recovery Symposium, Society of Petroleum Engineers.

29 Stavland A., Andersen K.I., Sandoey B., Tjomsland T., Mebratu A.A. (2006) How to apply a blocking gel system for bullhead selective water shutoff: from laboratory to field. SPE/DOE Symposium on Improved Oil Recovery, Society of Petroleum Engineers.

30 Chauveteau G., Tabary R., Le Bon C., Renard M., Feng Y., Omari A. (2003) In-depth permeability control by adsorption of soft size-controlled microgels. SPE European Formation Damage Conference, Society of Petroleum Engineers.

31 Bai B., Liu Y., Coste J.P., Li L. (2007) Preformed particle gel for conformance control: transport mechanism through porous media, SPE Reserv. Evalu. Eng. 10, 02, 176-184.

32 Goudarzi A., Zhang H., Varavei A., Taksaudom P., Hu Y., Delshad M., Bai B., Sepehrnoori K. (2015) A laboratory and simulation study of preformed particle gels for water conformance control, Fuel 140, 502-513.

33 Coste J.P., Liu Y., Bai B., Li Y., Shen P., Wang Z., Zhu G. (2000) In-depth fluid diversion by pre-gelled particles. Laboratory study and pilot testing. SPE/DOE Improved Oil Recovery Symposium, Society of Petroleum Engineers. 
34 Bai B., Zhang H. (2011) Preformed-particle-gel transport through open fractures and its effect on water flow, SPE J. 16, 02, 388-400.

35 Zhang H., Challa R.S., Bai B., Tang X., Wang J. (2010) Using screening test results to predict the effective viscosity of swollen superabsorbent polymer particles extrusion through an open fracture, Ind. Eng. Chem. Res. 49, 23, 12284-12293.

36 Imqam A., Bai B., Al Ramadan M., Wei M., Delshad M., Sepehrnoori K. (2015) Preformed-particle-gel extrusion through open conduits during conformance-control treatments, SPE J. 20, 05, 1083-1093.

37 Elsharafi M.O., Bai B. (2012) Effect of weak preformed particle gel on unswept oil zones/areas during conformance control treatments, Ind. Eng. Chem. Res. 51, 35, 11547-11554.

38 Bai B., Li L., Liu Y., Liu H., Wang Z., You C. (2007) Preformed particle gel for conformance control: factors affecting its properties and applications, SPE Reserv. Evalu. Eng. 10, 04, 415-422.

39 Xie Q., Pu W., Xing Y. (2006) Experimental study on seal-off behavior of pre-crosslinked gel, Spec. Oil Gas Reserv. 13, 4, 92-93.

40 Cui X. (2011) A study on the heterogeneous combination flooding system, Acta Petrolei Sinica 32, 1, 122-126.
41 Sang Q., Li Y., Yu L., Li Z., Dong M. (2014) Enhanced oil recovery by branched-preformed particle gel injection in parallel-sandpack models, Fuel 136, 295-306.

42 Yu L., Li Y., Gong H., Sang Q., Li K., Dong M. (2016) EOR of branched-preformed particle gel (B-PPG) flooding after polymer flooding in heterogeneous reservoirs, Petroleum Geology and Recovery Efficiency 23, 1, 113-118.

43 Gong H., Zhang H., Xu L., Li K., Yu L., Li Y., Dong M. (2017) Further enhanced oil recovery by branched-preformed particle gel/HPAM/surfactant mixed solutions after polymer flooding in parallel-sandpack models, RSC Adv. 7, 63, 39564-39575.

44 Gong H., Zhang H., Xu L., Li K., Yu L., San Q., Li Y., Dong M. (2017) The synergistic effect of branched-preformed particle gel and hydrolyzed polyacrylamide on furtherenhanced oil recovery after polymer flooding, Energy Fuels 31, 8, 7904-7910.

45 Seright R.S. (1988, January) Placement of gels to modify injection profiles. SPE Enhanced Oil Recovery Symposium, Society of Petroleum Engineers.

46 Liu Y., Liu J., Li X. (2001) Application of pre-crosslinked gel particles to depth profile control, Petroleum Geology and Recovery Efficiency 8, 3, 65-66.

47 Alvarado D., Marsden, Jr. SS (1979) Flow of oil-in-water emulsions through tubes and porous media, SPE J. 19, 06, 369-377. 